\section{Chlamydia pneumoniae}

In 1986 Grayston and coworkers described a new Chlamydia psittaci strain isolated from eight students at the University of Washington, Seattle, who had acute respiratory tract infections. ${ }^{1}$ This was the culmination of many years of work by Grayston and his team. The first isolate, TW-183, was obtained from the eye of a primary school child on Twain in October $1965 .^{2}$ It was not $C$ trachomatis. The next set of isolates was obtained from adults with acute respiratory disease, ${ }^{2}$ so Grayston named this new microorganism Chlamydia psittaci strain TWAR-TW from "TWAIN" and AR from "acute respiratory." Subsequently, this microorganism has been shown to be the third species of Chlamydia and is now known as $C$ pneumoniae. ${ }^{3} C$ pneumoniae is compared with $C$ trachomatis and $C$ psittaci in the table. ${ }^{4-7}$

\section{Features of Chlamydia pneumoniae}

Initially $C$ pneumoniae was thought to have pear shaped elementary bodies that were distinct from those of $C$ psittaci and $C$ trachomatis $^{3}$; additional studies in two cell lines, however, found no unique morphological features of this microorganism. ${ }^{8} C$ pneumoniae undergoes the same developmental cycle as $C$ trachomatis. ${ }^{9}$ The elementary body has an average size of $0.38 \mu \mathrm{m}$ and the reticulate body an average diameter of $0.51 \mu \mathrm{m} .{ }^{3}$ The major outer membrane protein of $C$ pneumoniae is less antigenically complex than that of the other chlamydial species and it is not the immunodominant antigen recognised during infection. ${ }^{10} \mathrm{~A}$ $60 \mathrm{kDa}$ protein of $C$ pneumoniae is an analogue of the $C$ trachomatis delayed type hypersensitivity antigen and the Escherichia coli heat shock protein. ${ }^{11}$ It has been suggested that repeated exposure to the chlamydia delayed type hypersensitivity antigen contributes to the deleterious effects of $C$ trachomatis and $C$ psittaci infection ${ }^{11}$ and, by inference, to the growing list of extrapulmonary manifestations of $C$ pneumoniae infection.

\section{Diagnosis}

Many of the studies that have elucidated the epidemiology of $C$ peumoniae have relied on serological criteria for diagnosis. ${ }^{12-17}$ In general, serological studies used the elementary body antigens of the TWAR strain in a microimmunofluorescence test. ${ }^{12}$ The usual criteria for acute infection are: fourfold or greater rise in either the $\operatorname{IgM}$ or

Selected features of three Chlamydia species ${ }^{47}$

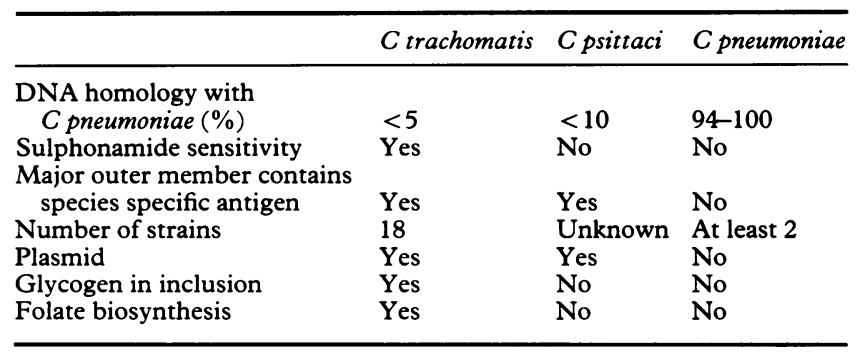

the IgG antibody or IgM antibody at a titre of $\geqslant 1 / 16$ and/or IgG antibody at a titre $\geqslant 1 / 512 .{ }^{12}{ }^{16}$ Recent observations suggest that at least one other strain, FML-10, should be included in the microimmunofluorescence test ${ }^{67}$ as some patients develop a rise in antibody to the FML-10 strain and not to TW-183, the usual strain used in this assay. Routine absorption of IgG before IgM testing is recommended to prevent false positive IgM results due to rheumatoid factor. ${ }^{18}$ Verkooyen et al after correction for rheumatoid factor interference in the microimmunofluorescence assay reduced the number of IgM positive results from 64 to $29 .{ }^{18}$ They also found that the prevalence of rheumatoid factor was age related, ranging from none in subjects under 30 years of age to $14 \%$ in those of $51-70 .{ }^{18}$ These observations are relevant to the interpretation of the results of older studies on the seroepidemiology of $C$ pneumoniae. Campbell et $a l^{19}$ showed that similar immunoreactivity against $C$ pneumoniae proteins was seen in patients with $C$ pneumoniae infection confirmed by both culture and serology and those who had a serological diagnosis only. Convalescent serum samples reacted with $98,68,60,39 \cdot 5$, and $30 \mathrm{kDa}$ proteins. The $98 \mathrm{kDa}$ protein seemed to be $C$ pneumoniae specific.

Isolation of $C$ pneumoniae is difficult. The initial studies used HeLa cells ${ }^{120}$; but with the discovery that the HEp-2 cell line supports growth of $C$ pneumoniae best isolation from clinical specimens may become easier. ${ }^{21}$

Polymerase chain reaction techniques are available for the diagnosis of $C$ pneumoniae infection. ${ }^{223}$ They have not, however, yet been applied in a routine clinical laboratory.

An enzyme immunosorbent assay has been used to detect $C$ pneumoniae antigen in sputum samples. ${ }^{24}$ The principle of this test is as follows. A genus specific Chlamydia test using a genus specific lipopolysaccharide monoclonal antibody is used to detect Chlamydia antigen, and then a $C$ trachomatis species specific test is used for direct visualisation of elementary bodies, a monoclonal antibody reacting to a major outer membrane protein being used. If the genus specific Chlamydia test gives a positive result but the species specific test gives a negative one the organism is presumed to be $C$ pneumoniae or $C$ psittaci, whereas if the specimen gives a positive result in all three Chlamydia tests $C$ trachomatis is assumed to be present.

\section{Epidemiology}

Man is the only known reservoir for $C$ pneumoniae 9 and person to person spread is the probable mode of acquisition. ${ }^{25}$ The symptomless carrier state ${ }^{2627}$ and prolonged excretion of the organism-for up to one year in some instances ${ }^{28}$-helps this type of transmission. In one study $11(4.7 \%)$ of 234 healthy subjects had $C$ pneumoniae isolated from throat cultures. ${ }^{27}$ Asymptomatic carriage of $C$ pneumoniae by children may pose a problem during evaluation for possible sexual assault. Bauwens et $a l^{9}$ isolated $C$ pneumoniae from the oropharynx of two children who had been sexually assaulted, but initially $C$ trachomatis infection had been diagnosed. There is no evidence of sexual transmission of $C$ pneumoniae. ${ }^{30}$ 
$C$ pneumoniae infection is rare in children under 5 years old. There is a bimodal distribution of infection with a peak at 8-9 years and another starting at $70 .{ }^{4}$ Grayston examined 2000 paired serum samples stratified by year, age, and sex from a large study of pneumonia in Seattle during 1963$75 .^{4}$ Eight per cent had evidence of acute $C$ pneumoniae infection, an incidence rate of $1 / 1000$ a year. The incidence among 70 year olds was $3 / 1000$ a year. ${ }^{4} C$ pneumoniae infection is worldwide and by early adulthood $30-50 \%$ of the population has serological evidence of infection, ${ }^{9}$ most of it subclinical. The seropositivity rate is usually higher in males. ${ }^{12}$

$C$ pneumoniae is primarily but not exclusively a respiratory pathogen. It is both endemic and epidemic. The first epidemics were in Scandinavia, ${ }^{14}{ }^{17} 31-33$ where Fryden $e t$ $a l^{32}$ found that the clinical picture of $C$ pneumoniae infection did not differ from that of "ornithosis." Indeed, these outbreaks were initially attributed to $C$ psittaci.

Chlamydia pneumoniae accounts for $6-10 \%$ of cases of community acquired pneumonia in patients admitted to hospital, ${ }^{12} 2034$ and it may also account for some cases of nosocomial pneumonia. ${ }^{35}$ But $70-90 \%$ of $C$ pneumoniae infections are subclinical, ${ }^{5}$ and reinfection may occur. ${ }^{14}$

Aldous et al ${ }^{15}$ examined 3671 serum samples from 343 subjects in 68 families obtained as part of a longitudinal study of viral and mycoplasma infections among families in the Seattle "virus watch" study from 1966 to 1979 . Fifty eight people had 64 infections. Ten of the 16 infections among adults were reinfections. Reinfection was defined as a fourfold or greater rise in IgG antibody in a subject with IgG antibody in a previous serum sample. Thirty nine of the 48 infections in children were primary or first infections and eight were reinfections; one could not be classified. During follow up the antibody titre declined to less than 1:8 (a negative level) as early as 16 months after the rise to as late as nine years. Antibody persisted longer and with less decline in titre after reinfection than after primary infection, especially in adults. ${ }^{15}$ Spread of $C$ pneumoniae infections within the family occurs-there were 41 episodes of infection among 32 families.

\section{Clinical features}

The clinical features of $C$ pneumoniae pneumonia are not distinctive. ${ }^{12}$ Primary infection causes mild pneumonia or prolonged bronchitis in teenagers and young adults. In older adults with the reinfection form of $C$ pneumoniae pneumonia it is not clear how important $C$ pneumoniae is because copathogens are usually present. ${ }^{5}$

A comparison of the clinical features of infections due to $C$ pneumoniae, Mycoplasma pneumoniae, and respiratory tract viruses showed that patients with $C$ pneumoniae infection were more likely to be hoarse and afebrile, and to have symptoms longer before seeking medical attention. ${ }^{36}$

$C$ pneumoniae also causes sinusitis, otitis media, tonsillitis, laryngitis, bronchitis, and pharyngitis. ${ }^{37-40} C$ pneumoniae has been isolated from a pleural effusion that complicated a right middle lobe pneumonia in a 19 year old man. ${ }^{41}$ The fluid contained $27.5 \times 10^{9} / 1$ white blood cells, the glucose concentration was $4.39 \mathrm{mmol} / \mathrm{l}$, and the $\mathrm{pH}$ was $7 \cdot 49$.

$C$ pneumoniae was isolated from five of 50 bronchoalveolar lavage specimens obtained from HIV infected patients with pneumonia, 41 of whom had AIDS. ${ }^{42}$ Four of these five specimens contained other pulmonary pathogens-Pneumocystis carinii in two cases and Mycobacterium tuberculosis in two. In another man with HIV infection $C$ pneumoniae mimicked Pneumocystis carinii infection in that diffuse bilateral interstitial infiltrates were present. He recovered after treatment with doxycyline. ${ }^{43}$
Other emerging pathogenetic roles for $C$ pneumoniae are the causation of pneumonia in patients with sickle cell disease $^{44}$ and with culture negative endocarditis. ${ }^{45}$

$C$ pneumoniae, like $M$ pneumoniae pneumonia, may be complicated by extrapulmonary manifestations, and so far erythema nodosum, thyroiditis, encephalitis, and the Guillain-Barré syndrome have been described. ${ }^{32} 46$

Hahn et al ${ }^{47}$ noted an association between $C$ pneumoniae infection and wheezing. Three of their 19 patients with acute $C$ pneumoniae infection wheezed at the time of enrolment in the study and five developed wheezing during the course of their illness. These investigators also noted that as the $C$ pneumoniae antibody titre increased so did the incidence of wheezing.

Somewhat surprisingly, after this litany of diverse manifestations, no association of $C$ pneumoniae and chronic fatigue syndrome has been documented. ${ }^{48}$

Experimental infection of non-human primates with $C$ pneumoniae failed to cause pneumonia but did result in conjunctival infection; the organism has been isolated from the rectal mucosa of these animals. ${ }^{49} 50$

\section{Association with coronary artery disease}

An intriguing observation, initially made by Saikku et al in $1988^{51}$ and subsequently expanded by this group ${ }^{52}$ and others, ${ }^{5354}$ is a relationship between $C$ pneumoniae antibody and coronary artery disease. The Helsinki heart study enabled Saikku et $a l^{52}$ to expand their original observations. As part of this study participants had blood samples collected regularly. Serum samples collected from 103 patients three to six months before a cardiac endpoint (fatal or non-fatal myocardial infarction or sudden death) were tested for antibodies to $C$ pneumoniae. These patients were then matched with control subjects for time point, locality, and treatment. The odds ratio for coronary heart disease was $2 \cdot 7$ for raised titres of $\operatorname{IgA}$ antibody to $C$ pneumoniae, $2 \cdot 1$ for the presence of $C$ pneumoniae immune complexes, and 2.9 for the presence of both. These workers postulated that the mechanism for this increased risk is as follows. Chlamydial lipopolysaccharide binds to low density lipoproteins, modifying the lipoprotein and making it immunogenic or toxic to endothelial cells. Modified or antibody associated low density lipoprotein is known to cause foam cell formation in vitro, a process considered to be the first phase in the development of atherosclerosis. Chlamydia organisms and their liposaccharide components are also potent inducers of tumour necrosis factor, which inhibits lipoprotein lipase, leading to altered lipid metabolism and the accumulation of triglycerides in the bloodstream. ${ }^{52}$ Thom et al ${ }^{53}$ showed that the risk associated with a high $C$ pneumoniae antibody titre was greatest for those with five or more angiographically confirmed lesions. In a second study Thom and coworkers ${ }^{54}$ carried out a casecontrol study to define the relationship of $C$ pneumoniae infection and coronary artery disease. They adjusted for age, gender, serum cholesterol concentration, hypertension, alcohol use, socioeconomic status, and the calendar quarter in which the blood sample was obtained. An association between $C$ pneumoniae antibody and coronary artery disease persisted but it was limited to cigarette smokers (odds ratio $3 \cdot 6,95 \%$ confidence interval $1 \cdot 7-70$ ). There was no linear relationship, however, with antibody titre. They consider that a prospective cohort study is necessary to investigate the association between $C$ pneumoniae infection and the development of atherosclerotic disease.

\section{Treatment}

Susceptibility testing of $C$ pneumoniae is greatly influenced 
by the timing of the addition of the antibiotic to the cell line. If it is added before $C$ pneumoniae infection the minimum inhibitory concentrations and minimum lethal concentrations are up to eight times lower than if it is added after the cells have been infected. ${ }^{55}$ Clarithromycin seems to be the most active antimicrobial against $C$ pneumoniae. ${ }^{556}$ In other studies azithromycin, erythromycin, and tetracycline were active against it. ${ }^{57}$ There have, however, been no controlled clinical trials to determine the appropriate antimicrobial and its dose and duration for the treatment of $C$ pneumoniae infections. Empirical observations suggest that relapses are frequent if erythromycin is given for less than three weeks. ${ }^{5}$ Four patients with $C$ pneumoniae infection-two with pneumonia and two with bronchitis-who were treated with ofloxacin $400 \mathrm{mg}$ twice daily for two weeks were cured. ${ }^{58}$ Tetracycline treatment for two weeks has not been followed by relapses. ${ }^{5}$

\section{The future}

We have learned a lot about this "new" pathogen in the short time since its discovery by Grayston. The challenges for the next few years are to refine the polymerase chain reaction test for $C$ pneumoniae, so that it can be used in routine diagnostic laboratories, and to clarify the relationship of $C$ pneumoniae infection and coronary artery disease. The evidence that $C$ pneumoniae may cause irritable airways needs confirmation and-even more importantwe need to know whether appropriate treatment of $C$ pneumoniae will hasten resolution of the associated airway irritability.

THOMAS J MARRIE Departments of Medicine and Microbiology, Dalhousie University and Victoria General Hospital, Halifax, Nova Scotia, Canada B 3 H 2 Y

Reprint requests to: Dr TJ Marrie, 1278 Tower Road, Room 4090 ACC Reprint requests to: Dr TJ Marrie, 1278

1 Grayston JT, Kuo C-C, Wang S-p, Altman J. A new Chlamydia psittaci strain, TWAR, isolated in acute respiratory tract infections. $N$ Engl J Med 1986;315:161-8.

2 Kuo C-C, Chen HH, Wang S-p, Grayston JT. Characterization of TWAR strains, a new group of Chlamydia psittaci. In: Oriel D, Ridgway G, Schachter J, Taylor-Robinson D, Ward M, eds. Chlamydial infections. Proceedings of the sixth international symposium on human chlamydial infections. Cambridge: Cambridge University Press, 1987:321-4.

3 Grayston JT, Kuo C-C, Campbell LA, Wang S-p. Chlamydia pneumoniae sp. nova for Chlamydia sp strain TWAR. Int $J$ Sys Bacteriol 1989;39: 88-90.

4 Grayston JT. Chlamydia pneumoniae, strain TWAR pneumonia. Annu Rev Med 1992;43:317-23.

5 Grayston JT. Chlamydia pneumoniae, strain TWAR. Chest 1989;95:664-9.

6 Berdal BP, Fields PI, Melbye H. Chlamydial pneumoniae respiratory tract infection: The interpretation of high titres in the complement fixation test. Scand J Infect Dis 1991;23:305-7.

7 Black CM, Johnson JE, Farshy CE, Brown TM, Berdal BP. Antigenic variation among strains of Chlamydia pneumoniae. J Clin Microbio 1991;29:1312-6.

8 Popov VL, Shatkin AA, Pankratova VN, Smirnova NS, von Bonsdorff C-H, Ekman M-R, et al. Ultrastructure of Chlamydia pneumoniae in cell culture. FEMS Microbiol Lett 1991;84:129-34.

9 Grayston JT, Wang SP, Kuo C-C, Campbell LA. Current knowledge on Chlamydia pneumoniae, strain TWAR, an important cause of pneumonia and other acute respiratory diseases. Eur J Clin Microbiol Infect Dis 1989, 8:191-202.

10 Perez Melgosa M, Kuo C-C, Campbell LA. Sequence analysis of the major outer membrane protein gene of Chlamydia pneumoniae. Infect Immun 1991;59:2195-9.

11 Kikuta LC, Puolakkainen M, Kuo C-C, Campbell LA. Isolation and sequence analysis of the Chlamydia pneumoniae Gro EL operon. Infect Immun 1991;59:4665-9.

12 Marrie TJ, Grayston JT, Wang SP, Kuo CC. Pneumonia associated with the TWAR strain of Chlamydia. Ann Intern Med 1987;106:507-11.

13 Bruu A-L, Aasen S, Tjaland S, Birkeland Flugsrud L. An outbreak of ornithosis in Norway in 1981. Scand J Infect Dis 1984;16:145-52.

14 Kleemola M, Saikku P, Visakorpi R, Wang SP, Grayston JT. Epidemics of pneumonia caused by TWAR, a new Chlamydia organism, in military trainees in Finland. J Infect Dis 1988;157:230-6.

15 Aldous MB, Grayston JT, Wang SP, Foy HM. Seroepidemiology of Chlamydia pneumoniae TWAR infection in Seattle families, 1966-1979.
J Infect Dis 1992;166:646-9.

16 Pether JVS, Wang SP, Grayston JT. Chlamydia pneumoniae, strain TWAR, as the cause of an outbreak in a boy's school previously called psittacosis. Epidemiol Inf 1989;103:395-400.

17 Persson K, Treharne J. Diagnosis of infection caused by Chlamydia pneumoniae (strain TWAR) in patients with "ornithosis" in Southern Sweden 1981-1987. Scand J Infect Dis 1989;21:675-9.

18 Verkooyen RP, Hazenberg MA, van Haaren GH, Van Den Bosch JM, Snijder RJ, van Helden HP, et al. Age-related interference with Chlamydia pneumoniae microimmunofluorescence serology due to circulating rheumatoid factor. J Clin Microbiol 1992;30:1287-90.

19 Campbell LA, Kuo C-C, Wang S-P, Grayston JT. Serological response to Chlamydia pneumoniae infection. J Clin Microbiol 1990;28:1261-4.

20 Campbell JF, Barnes RC, Kozarsky PE, Spika JS. Culture-confirmed pneumonia due to Chlamydia pneumonia. J Infect Dis 1991;164:411-3.

21 Roblin PM, Dumornay W, Hammerschlag MR. Use of Hep-2 cells for improved isolation and passage of Chlamydia pneumoniae. J Clin Microbiol 1992;30:1968-71.

22 Holland SM, Gaydos CA, Quinn TC. Detection and differentiation of Chlamydia trachomatis, Chlamydia psittaci, and Chlamydia pneumoniae by DNA amplification. J Infect Dis 1990;162:984-7.

23 Gaydos CA, Quinn TC, Eiden JJ. Identification of Chlamydia pneumoniae by DNA amplification of the 16s rRNA gene. J Clin Microbiol 1992;30: 796-800.

24 Sillis M, White P. Rapid identification of Chlamydia psittaci and TWAR (C. pneumoniae) in sputum samples using an amplified immunoassay. $J$ Clin Pathol 1990;42:260.

25 Yamazaki T, Nakada H, Sakurai N, Kuo C-C, Wang SP, Grayston JT. Transmission of Chlamydia pneumoniae in young children in a Japanese family. J Infect Dis 1990;162:1390-2.

26 Hyman CL, Augenbraun MH, Roblin PM, Schachter J, Hammerschlag MR. Asymptomatic respiratory tract infection with Chlamydia pneumoniae TWAR. J Clin Microbiol 1991;29:2082-3.

27 Gnarpe J, Gnarpe H, Sundelof B. Endemic prevalence of Chlamydia pneumoniae in subjectively healthy persons. Scand J Infect Dis 1991;23: 387-8.

28 Chirgwin K, Roblin PM, Gelling M, Hammerschlag MR, Schachter J. Infection with Chlamydia pneumoniae in Brooklyn. J Infect Dis 1991; 163:757-61.

29 Bauwens JE, Gibbons MS, Hubbard MM, Stamm WE. Chlamydia pneumoniae (strain TWAR) isolated from two symptom free children during evaluation for possible sexual assault. J Pediatr 1991;119:591-3.

30 Li De-Bun, Daling JR, Wang S-P, Grayston JT. Evidence that Chlamydia pneumoniae, strain TWAR is not sexually transmitted. $J$ Infect Dis 1989;160:328-31.

31 Grayston JT, Mordhorst C, Bruu A-L, Vene S, Wang S-P. Country-wide epidemic of Chlamydia pneumoniae, strain TWAR, in Scandinavia, 19811983. J Infect Dis 1989;159:1111-4.

32 Frydén A, Kihlström E, Maller R, Persson K, Romanus V, Ånséhn S. A. clinical and epidemiological study of "ornithosis" caused by Chlamydia psittaci and Chlamydia pneumoniae (strain TWAR). Scand J Infect Dis 1980;21:681-91.

33 Bruu A-L, Haukenes G, Aasen S, Grayston JT, Wang S-P, Klausen OG, et al. Chlamydia pneumoniae infections in Norway 1981-87 earlier diagnosed as ornithosis. Scand J Infect Dis 1991;23:299-304.

34 Fang GD, Fine M, Orloff J, Arisumi D, Yu VL, Kapoor W, et al. New and emerging etiologies for community-acquired pneumonia with implications for therapy. A prospective multicenter study of 359 cases. Medicine (Baltimore) 1990;69:307-16.

35 Grayston JT, Diwan VK, Cooney M, Wang S-P. Community and hospitalacquired pneumonia associated with Chlamydia TWAR infection demonstrated serologically. Arch Intern Med 1989;149:169-73.

36 Thom DH, Grayston JT, Wang S-P, Kuo C-C, Altman J. Chlamydia pneumoniae strain TWAR, Mycoplasma pneumoniae and viral infections in acute respiratory disease in a university health clinic. $A m \mathrm{~J}$ Epidemiol 1990;132:248-56.

37 Hashiguchi K, Ogawa H, Kazuyama Y. Seroprevalence of Chlamydia pneumoniae infections in otolaryngeal diseases. J Laryngol Otol 1992;106: 208-10.

38 Huovinen $P$, Lahtoner $R$, Ziegler $T$, Meurman $O$, Hakkarainen $K$, Miettinen A, et al. Pharyngitis in adults: the presence and coexistence of viruses and bacterial organisms. Ann Intern Med 1989;110:612-6.

39 Ogawa H, Fujisawa T, Kazuyama Y. Isolation of Chlamydia pneumonia from the middle ear aspirates of otitis media with effusion. Case report. $J$ Infect Dis 1990;162:1000-1.

40 Beaty CD, Grayston JT, Wang S-P, Kuo C-C, Reto CS, Martin TR Chlamydia pneumoniae strain TWAR in patients with chronic obstructive pulmonary disease. Am Rev Respir Dis 1991;144:1408-10.

41 Augenbraun MH, Roblin PM, Mandel LJ, Hammerschlag MR, Schachter J. Chlamydia pneumoniae pneumonia with pleural effusion: diagnosis by culture. Am J Med 1991;91:437-8.

42 Augenbraun MH, Roblin PM, Chirgwin K, Landman D, Hammerschlag MR. Isolation of Chlamydia pneumoniae from the lungs of patients infected with the human immunodeficiency virus. J Clin Microbiol 1991;29:401-2.

43 Clark R, Mashatt D, Fazal B. Case Report. Chlamydia pneumoniae pneumonia in an HIV-infected man. Am J Med Sci 1991;302:155-6.

44 Miller ST, Hammerschlag MR, Chirgwin K, Rao SP, Roblin P, Cassel G. Role of Chlamydia pneumoniae in acute chest syndrome in sickle cell disease. J Pediatr 1991;118:30-3.

45 Marrie TJ, Harczy M, Mann OE, Landymore RW, Raza A, Wang S-P, et al. Culture negative endocarditis probably due to Chlamydia pneumoniae. $J$ Infect Dis 1990;161:127-9.

46 Haidl S, Ivarsson S, Bjerre I, Persson K. Guillain-Barré syndrome after Chlamydia pneumoniae infection. $N$ Engl J Med 1992;326:576-7.

47 Hahn DL, Dodge RW, Golubjatnikov R. Association of Chlamydia pneumoniae (strain TWAR) infection with wheezing, asthmatic bronchitis, and adult-onset asthma. JAMA 1991;266:225-30.

48 Komaroff AL, Wang S-P, Lee J, Grayston JT. No association of chronic 
Chlamydia pneumoniae infection with chronic fatigue syndrome. J Infect Dis 1992;165:184.

49 Bell TA, Kuo C-C, Wang SP, Grayston JT. Experimental infection of baboons (Papio cynocephalus anubis) with Chlamydia pneumoniae strain TWAR. J Infect 1989;19:47-9.

50 Holland SM, Taylor HR, Gaydos CA, Kiappus EW, Quinn TC. Experimental infection with Chlamydia pneumoniae in nonhuman primates. Infect Immun 1990;58:593-7.

51 Saikku P, Leinonen M, Mattila K, Ekman M-R, Nieminen MS, Makela PH, et al. Serological evidence of an association of a novel Chlamydia TWAR, with chronic coronary artery disease and acute myocardial infarction. Lancet 1988;ii:983-6.

52 Saikku P, Leinonen M, Tenkanen L, Linnanmaki E, Ekman M-R Manninen V, et al. Chronic Chlamydia pneumoniae infection as a risk facto for coronary heart disease in the Helsinki Heart Study. Ann Intern Med 1992;116:273-8.

53 Thom DH, Wang S-P, Grayston JT, Siscovick DS, Stewart DK, Kronmal $\mathrm{RA}$, et al. Chlamydia pneumoniae strain TWAR antibody and angio- graphically demonstrated coronary artery disease. Arteriosclero Thromb 1991;11:547-51.

54 Thom DH, Grayston JT, Siscovick DS, Wang S-P, Weiss NS, Daling JR. Association of prior. infection with Chlamydia pneumoniae and angiographically demonstrated coronary artery disease. JAMA 1992;268: 6raphicall.

55 Cooper MA, Baldwin D, Matthews RS, Andrews JM, Wise R. In vitro susceptibility of Chlamydia pneumoniae (TWAR) to seven antibiotics. $J$ Antimicrob Chemother 1991;28:407-13.

56 Ridgway GL, Mumtaz G, Fenelon L. The in-vitro activity of clarithromycin and other macrolides against the type strain of Chlamydia pneumoniae (TWAR). J Antimicrob Chemother 1991;27 (suppl A):43-5.

57 Chirgwin K, Roblin PM, Hammerschlag MR. In vitro susceptibilities of Chlamydia pneumoniae (Chlamydia sp strain TWAR). Antimicrob Agents Chemother 1989;33:1634-5.

58 Lipsky BA, Tack KJ, Kuo C-C, Wang S-P, Grayston JT. Ofloxacin treatment of Chlamydia pneumoniae (strain TWAR) lower respiratory tract infections. Am J Med 1990;89:722-4. 